SABRAO Journal of Breeding and Genetics

53 (4) 632-644, 2021

http://doi.org/10.54910/sabrao2021.53.4.7

http://sabraojournal.org/

pISSN 1029-7073; eISSN 2224-8978

\title{
RICE BACKCROSS POPULATION ASSESSMENT FOR IRON TOLERANCE THROUGH PHENOTYPIC AND GENOTYPIC ANALYSES
}

\author{
V.T. TAM ${ }^{1,2}$, L.T. VY ${ }^{2}$, N.T. HUU ${ }^{2}$ and P.T.T. HA ${ }^{1,2 *}$ \\ ${ }^{1}$ Genomic Research Institute and Seed, Ton Duc Thang University, Ho Chi Minh City, Vietnam \\ ${ }^{2}$ Faculty of Applied Sciences, Ton Duc Thang University, Ho Chi Minh City, Vietnam \\ *Corresponding author email: phamthithuha@tdtu.edu.vn, ORCID: 0000-0002-6767-5761 \\ Email addresses of co-authors: vthanhtm29@gmail.com, laithanhvyy@gmail.com, \\ huutrongnguyen1999@gmail.com
}

\section{SUMMARY}

Iron toxicity has become a serious issue affecting rice (Oryza sativa L.) production in many irrigated lowland areas. The selection of $\mathrm{Fe}^{2+}$-tolerant rice cultivars under iron toxicity conditions and the identification of molecular markers are good approaches to obtaining tangible results. This study aimed to identify simple sequence repeat (SSR) markers that were associated with iron tolerance traits in a rice backcross population. A total of 117 seedlings from the backcross $\left(\mathrm{BC}_{3} \mathrm{~F}_{2}\right)$ of 'OM6830'/AS996'//'AS996' were phenotyped at the 4-week-seedling stage at Ton Duc Thang University, Ho Chi Minh City, Vietnam. The rice population was screened in Yoshida nutrient medium supplemented with $\mathrm{FeCl}_{2}$ at a concentration of $150 \mathrm{mg} \mathrm{L}^{-1}$ under greenhouse conditions. Phenotypic analysis was conducted by scoring two parameters, namely, root length and leaf bronzing. Genotypic analysis was carried out on the $\mathrm{BC}_{3} \mathrm{~F}_{2}$ population by using four markers, i.e., RM6, RM240, $\mathrm{RM} 252$, and $\mathrm{RM} 451$, for association analysis with iron tolerance. $A$ total of $23 \mathrm{BC}_{3} \mathrm{~F}_{2}$ lines were selected on the basis of their higher tolerance (score 1) for $\mathrm{Fe}^{2+}$ compared with the tolerant parental line 'AS996'. The markers RM6 and RM240 were highly polymorphic and identified different $\mathrm{Fe}^{2+}$-tolerant lines in the $\mathrm{BC}_{3} \mathrm{~F}_{2}$ population. Among the $\mathrm{BC}_{3} \mathrm{~F}_{3}$ progeny derived from the selected $23 \mathrm{BC}_{3} \mathrm{~F}_{2}$ lines, $\mathrm{BC}_{3} \mathrm{~F}_{3}-7$ was identified as the most $\mathrm{Fe}^{2+}$-tolerant line. $\mathrm{BC}_{3} \mathrm{~F}_{3}-15$ was also found to be $\mathrm{Fe}^{2+}$ tolerant. Both lines showed good development capability and provided high yields under stress conditions. These tolerant $\mathrm{BC}_{3} \mathrm{~F}_{3}$ lines could be further screened with additional SSR markers in future breeding programs aiming to increase rice production in iron-contaminated areas of the Mekong Delta, Vietnam.

Keywords: Backcrosses, iron toxicity, phenotypic and genotypic traits, screening, SSR markers, genetic analysis, Oryza sativa L.

Key findings: Among the 117 rice lines derived through the backcross method, line $\mathrm{BC}_{3} \mathrm{~F}_{3}-$ 7 was selected as the most $\mathrm{Fe}^{2+}$-tolerant line by using the two highly polymorphic markers RM6 and RM240. $\mathrm{BC}_{3} \mathrm{~F}_{3}-15$ was found to be the next most $\mathrm{Fe}^{2+}$-tolerant line. The two rice lines displayed good growth and increased yield under $\mathrm{Fe}^{2+}$-stressed conditions. 


\section{INTRODUCTION}

Rice (Oryza sativa L.) is an important food crop that is consumed by more than half of the global population (Chakravarthi and Naravaneni, 2006). Global rice production reached 506.0 million tons (milled basis) in 2021 (FAO, 2021). Against the background of climate change, rice production is at risk of difficulties due to various environmental factors, such as heat, drought, salinity, flooding, and iron and aluminum toxicity (Dabi and Khanna, 2018). In recent years, the problem of iron toxicity has become a serious issue affecting rice production in irrigatedlowland areas (Sikirou et al., 2018), especially in Southeast Asia and West Asia. The occurrence of iron toxicity is associated with a high concentration of $\mathrm{Fe}^{2+}$ in the soil solution. In wetlands, iron toxicity has been reported to reduce rice yield by $20 \%-100 \%$ in accordance with soil iron and varietal tolerance levels (Sahrawat, 2004; Santos et al., 2019).

At low concentrations, iron is an essential micronutrient for plants; however, either a deficiency or an excess of iron inhibits plant growth (Seraj and Rahman, 2018). Acid sulfate soils that cause iron toxicity occupy approximately 1.5 million hectares of the Mekong River Delta, Mekong Delta, Vietnam. They are mainly distributed in Dong Thap Muoi, Tu Giac Long Xuyen, and West Song Hau and are also scattered in some other areas of Vietnam. Rice remains the main crop planted in these areas (Bong et al., 2018). Iron toxicity and aluminum toxicity are often considered to be two limiting factors for crop yield in acid soils. The increase in $\mathrm{pH}$ due to the reduction process that occurs when alum soil is submerged in water can limit aluminum toxicity but at the same time exacerbates iron toxicity. Iron toxicity affects growth and grain yield and is particularly severe at the early seedling stage (Liu et al., 2016). Rice breeding for iron toxicity tolerance has placed major emphasis on identifying resistance and harnessing genes for genetic and phenotypic improvement. The identification and development of new rice cultivars with high yield and quality traits are important factors for enhancing and stabilizing rice production in the country. Among the measures taken to limit iron toxicity in rice, the most effective is the selection and cultivation of varieties with high tolerance (Bresolin et al., 2019). Therefore, the selection of $\mathrm{Fe}^{2+}$-tolerant cultivars has been an important strategy and an effective measure to reduce rice yield losses (Stein et al., 2014; Mahender et al., 2019).

Field evaluation and selection are difficult to perform due to several factors, such as $G \times E$ interaction effects, and their need for time-consuming and costly trials. Therefore, molecular markers are considered as a tool for assisting the genotyping and selection of tolerant rice cultivars (Platten et al., 2019). Although classic breeding methods have shown efficiency in producing improved cultivars, marker-assisted selection further increases the effectiveness of breeding (Sakiyama et al., 2014). Adequate genotyping and phenotyping are important for the success of plant breeding with marker-assisted selection (Sakiyama et al., 2014). Large-scale genotyping is becoming faster, cheaper, and more automated (Sakiyama et al., 2014). Given that it is unaffected by environmental effects, it shortens the breeding cycle (Lincoln et al., 2018). By complementing phenotypic data, molecular markers improve the capability to compare genotypes even if these genotypes are sampled in different environments, tissue types, or developmental stages (Sakiyama et al., 2014). Genome-wide DNA polymorphisms are detected by using molecular markers (Sakiyama et al., 2014). In rice, many quantitative trait loci (QTL) for iron toxicity have been identified and mapped by using DNA markers (Zhang et al., 2017). Efforts to identify the QTL for iron tolerance have focused on easily measurable traits, such as leaf bronzing index, shoot and root dry weight, tiller number, plant height, root length, and iron accumulation in the shoot (Wan et al., 2003; Dufey et al., 2015). The 
combination of QTL mapping with markerassisted selection has become an effective breeding technique in the precise identification of genotypes (Collard and Mackill, 2007; Boopathi, 2020). DNA markers are used for multiple purposes, such as gene mapping, gene tagging, estimating genetic diversity, differentiating between cultivars, and purity testing (Nagaraju et al., 2002; Boopathi, 2020). Markers and laboratory testing are used in combination with field testing for the identification of traits that are most important to farmers, processors, and consumers to produce new crop varieties that are adapted to climate change and ensure food security. The current study aimed to identify new rice lines in backcrossed populations through a combination of phenotypic analysis and SSR markers related to high iron tolerance. The results of this work will provide a basis for planning the future breeding program of iron-tolerant rice cultivars for the Mekong Delta, Vietnam.

\section{MATERIALS AND METHODS}

\section{Plant material}

The genotype 'AS996', a Fe ${ }^{2+}$-tolerant line that was developed from a cross between 'IR64' and Oryza rufipogon, has been identified as strongly tolerant to acidsulfate soils (Buu and Lang, 1997, 2007). The susceptible parent 'OM6830' is a common rice variety collected from Cuu Long Delta Rice Research Institute (CLRRI), Vietnam. The $\mathrm{BC}_{3} \mathrm{~F}_{1}$ population was obtained by backcrossing the hybrid of the cross 'OM6830' $\times$ 'AS996' with the tolerant parent 'AS996'. The $\mathrm{BC}_{3} \mathrm{~F}_{2}$ ('OM6830'/'AS996'//'AS996') population was derived by self-pollinating each $\mathrm{BC}_{3} \mathrm{~F}_{1}$ plant. The $117 \quad \mathrm{BC}_{3} \mathrm{~F}_{2}$ lines and their parents were screened at Genomic Research Institute and Seed, Ton Duc Thang University, Ho Chi Minh City, Vietnam.

\section{Phenotypic analysis}

The recommended doses of $\mathrm{Fe}^{2+}$ that are used for screening iron toxicity tolerance are $100 \mathrm{mg} \mathrm{L}^{-1}$ at $4.0 \mathrm{pH}$ (Fageria and Robelo, 1987) and $200 \mathrm{Fe}^{2+} \mathrm{mg} \mathrm{L}^{-1}$ at 5.0 $\mathrm{pH}$ (Yamaguchi and Yoshida, 1981). However, in the current study, we applied $150 \mathrm{mg} \mathrm{L}^{-1} \mathrm{Fe}^{2+}$ in the solution for screening the rice population under the assumption that iron toxicity will increase in the future when annual flooding causes serious damage to Vietnam's agriculture and results in sulfate and iron toxicity (Nugroho et al., 2021).

The experiment was arranged in a randomized complete block design with three replications ( 9 rice seeds/3 holes) and carried out in the greenhouse. In the greenhouse, the temperature was maintained at $32{ }^{\circ} \mathrm{C} / 28{ }^{\circ} \mathrm{C}$ light/dark, and the relative humidity was varied from $85 \%$ to $90 \%$. The $117 \mathrm{BC}_{3} \mathrm{~F}_{2}$ lines and their parents were cultured hydroponically for 14 days in Yoshida solution. On the 14th day, $150 \mathrm{mg} \mathrm{L}^{-1} \mathrm{FeCl}_{2}$ solution was added to the solution, and the $\mathrm{pH}$ was maintained at 5.0. Samples were collected, and phenotypic evaluation was done 14 days after transfer to the $\mathrm{Fe}^{2+}$ solution. Root length was measured, and leaf bronzing was evaluated on a 1-9 scale at 4 weeks by following the Standard Evaluation System (SES) of the International Rice Research Institute (IRRI), Los Baños, Philippines (IRRI, 2002) (Table 1). Tolerance and susceptibility assessment was done on the basis of root length and leaf bronzing scores. On the basis of this phenotypic analysis, 23 tolerant lines were selected from $117 \mathrm{BC}_{3} \mathrm{~F}_{2}$ lines. These lines were subjected to genotypic analysis. Furthermore, the $\mathrm{BC}_{3} \mathrm{~F}_{3}$ population $\left(\mathrm{BC}_{3} \mathrm{~F}_{3}\right.$ 1 to $\left.\mathrm{BC}_{3} \mathrm{~F}_{3}-23\right)$ developed by selfpollinating the selected $\mathrm{BC}_{3} \mathrm{~F}_{2}$ plants that were used to evaluate yield and yield components in an iron-toxic environment. 
Table 1. SES for rice (IRRI, 2002).

\begin{tabular}{cl}
\hline Score & Symptoms \\
\hline 0 & Growth and tillering are nearly normal \\
1 & $\begin{array}{l}\text { Growth and tillering nearly normal; reddish-brown spots or orange discoloration } \\
\text { on the tips of older leaves }\end{array}$ \\
3 & $\begin{array}{l}\text { Growth and tillering nearly normal; older leaves reddish-brown purple or orange } \\
\text { yellow }\end{array}$ \\
7 & Growth and tillering retarded; many leaves discolored \\
9 & Almowth and tillering cease; most leaves discolored or dead
\end{tabular}

Note: Levels of $0-3$ on the SES scale are considered "tolerant" and those of 5-9 are "susceptible"

Table 2. Primer sequences of the molecular markers used for identifying the lines tolerant to iron toxicity.

\begin{tabular}{cllc}
\hline No. & Markers & Primer sequences used for gene detection (5'- 3') & Chromosome \\
\hline 1 & RM6 & F'GTCCCCTCCACCCAATTC' & 2 \\
2 & RM240 & $\begin{array}{l}\text { R'TCGTCTACTGTTGGCTGCAC' } \\
\text { F'CCTAATGGGTAGTGTGCAC' } \\
\text { R'TGTAACCATTCCTTCCATCC' }\end{array}$ & 2 \\
3 & RM252 & $\begin{array}{l}\text { R'TTCGCTGACGTGATAGGTT' } \\
\text { R'ATGACTTGATCCCGAGAACG' }\end{array}$ & 4 \\
& RM451 & $\begin{array}{l}\text { F'GATCCCCTCCGTCAAACAC' } \\
\text { R'GATCCCCTCCGTCAAACAC' }\end{array}$ & 4 \\
\hline
\end{tabular}

\section{Genotypic analysis}

The 23 selected $\mathrm{BC}_{3} \mathrm{~F}_{2}$ lines and the parental genotypes ('OM6830' and 'AS996') were used, and DNA was extracted via the CTAB method as described by Lang (2002). Four SSR markers (RM6 and RM240 on chromosome 2 and RM252 and RM451 on chromosome 4) were used to analyze the $\mathrm{BC}_{3} \mathrm{~F}_{2}$ population (Table 2 ).

Young leaf tissue (50 mg) was crushed by using a mortar and pestle with $400 \mu \mathrm{L}$ of extraction buffer $(100 \mathrm{mM}$ Tris$\mathrm{HCl}, 50 \mathrm{mM}$ EDTA, $500 \mathrm{mM} \mathrm{NaCl}, 1.25 \%$ [w/v] SDS, and $3.8 \mathrm{~g}$ per $\mathrm{L}$ sodium bisulfite). The mixture was added into a $2.2 \mathrm{~mL}$ tube and gently mixed with $400 \mu \mathrm{L}$ of chloroform:isopropanol (24:1) and centrifuged at $13000 \mathrm{rpm}$ for $1 \mathrm{~min}$. The supernatant was transferred into a new tube $(2.2 \mathrm{~mL})$ and added with $800 \mu \mathrm{L}$ of absolute ethanol. After freezing overnight, the suspension was centrifuged at 13000 $\mathrm{rpm}$ for $5 \mathrm{~min}$. The obtained pellet was washed with $500 \mu \mathrm{L}$ of $70 \%$ ethanol. The pellet was resuspended in $50 \mu \mathrm{L}$ of TE buffer and incubated at room temperature. DNA quality was tested by electrophoresis on $3 \%$ agarose gel in $1 \times$ TAE buffer for 7-10 min, and the DNA was visualized on a gel documentation system (Bio-Rad Gel Doc XR ${ }^{\mathrm{TM}}$ imaging system, California, USA) under UV light after staining with ethidium bromide.

Polymerase chain reaction (PCR) and simple-sequence repeat (SSR) analyses were performed with four primer pairs by using the template of the genomic DNA in accordance with Panaud et al. (1996) with certain modifications. In marker selection, PCR (Alpha Cycler, AC2, Staffordshire, United Kingdom) was performed by using a total volume of 12.5 $\mu \mathrm{L}$, which contained $6.25 \mu \mathrm{L}$ of the master mix (Qiagen), $0.5 \mu \mathrm{L}$ of primer $\mathrm{F}(10 \mathrm{mM})$, $1 \mu \mathrm{L}$ of DNA (40 ng/ $\mu \mathrm{L})$, and $4.25 \mu \mathrm{L}$ of $\mathrm{H}_{2} \mathrm{O}$. The PCR conditions were $94^{\circ} \mathrm{C}$ for 5 min followed by 29 cycles of $94^{\circ} \mathrm{C}$ for 1 $\min , 55^{\circ} \mathrm{C}$ for $1 \mathrm{~min}$, and $72{ }^{\circ} \mathrm{C}$ for $1 \mathrm{~min}$ with a final extension cycle of $5 \mathrm{~min}$ at 72 ${ }^{\circ} \mathrm{C}$. The PCR products were separated via 
electrophoresis (Mupid One, Takara, Japan) on $8 \%$ polyacrylamide gel $(2.4 \mathrm{~mL}$ of TBE $5 \times, 3.2 \mathrm{~mL}$ of acrylamide, $200 \mu \mathrm{L}$ of APS, $18 \mu \mathrm{L}$ of Tedmed, and $6.4 \mathrm{~mL}$ of $\mathrm{H}_{2} \mathrm{O}$ ), and the banding pattern was visualized by staining with ethidium bromide. The stained gels were photographed with a Gel Doc Molecular Imager (Bio-Rad Gel Doc XR ${ }^{T M}$ Imaging System, USA).

\section{Evaluation of yield and yield components}

The $23 \quad \mathrm{BC}_{3} \mathrm{~F}_{3}$ rice lines and the two parental varieties ('AS996' and 'OM6830') were screened in the field. The soil characteristics at the experimental site are shown in Table 3. Data measurements were obtained for yield and yield components: plant height $(\mathrm{cm})$, the number of tillers, panicle length $(\mathrm{cm})$, filled grain, unfilled grain (\%), 1000-grain weight $(\mathrm{g})$, and grain yield $(\mathrm{g})$.

\section{Data analysis}

The mean root lengths of the genotypes were calculated by using Excel software. The yield and yield parameters of the tolerant rice were analyzed by using the general linear model. Analysis of variance was performed with SPSS software 17.0 (SPSS Inc. Chicago, IL, USA), and Duncan's multiple range test was applied with a significant difference at the 0.05 level.

Table 3. Soil characteristics of the experimental site in O Mon, Can Tho City, Mekong Delta, Vietnam.

\begin{tabular}{lll}
\hline Characteristics & Unit & Value \\
\hline Clay & $\%$ & 62 \\
Loam & $\%$ & 33 \\
Sand & $\%$ & 5 \\
pH $(\mathrm{KCl})$ & & 3.9 \\
EC & $\mathrm{mS} / \mathrm{cm}$ & 0.37 \\
Total N & $\%$ & 0.17 \\
Available N & $\mathrm{Mg} / \mathrm{kg}$ & 70 \\
Total P & $\%$ & 0.06 \\
Available P & $\mathrm{Mg} / \mathrm{kg}$ & 4.64 \\
Total K & $\%$ & 1.12 \\
$\mathrm{~K}^{+}$ & $\mathrm{meq} / 100 \mathrm{~g}$ & 0.08 \\
Total Fe & $\mathrm{Mg} / \mathrm{kg}$ & 2.67 \\
Available Cu & $\mathrm{Mg} / \mathrm{kg}$ & 33.67 \\
Available $\mathrm{Zn}$ & $\mathrm{Mg} / \mathrm{kg}$ & 23.23 \\
Total Ca & $\%$ & 0.0024 \\
Ca & meq/100 g & 1.581 \\
Total Mg & $\%$ & 0.122 \\
Mg & meq/10 $0 \mathrm{~g}$ & 3.76 \\
Total Mn & $\%$ & 0.022 \\
CEC & $\mathrm{meq} / 100 \mathrm{~g}$ & 25 \\
\hline
\end{tabular}

Note: $\mathrm{KCl}$ - Potassium chloride; EC - Electrical conductivity; Total N - Total nitrogen; Available N - Available nitrogen; Total P - Total phosphorus; Available P - Available phosphorus; Total $\mathrm{K}$ - Total potassium; $\mathrm{K}^{+}$potassium ion; Total Fe - Total ferrite; Available Cu - Available copper; Available Zn - Available zinc; Total Ca Total calcium; $\mathrm{Ca}^{2+}$ - Calcium ion; $\mathrm{Mg}^{2+}-$ Magnesium ion; Total $\mathrm{Mn}$ - Total manganese; CEC - Cation exchange capacity. 


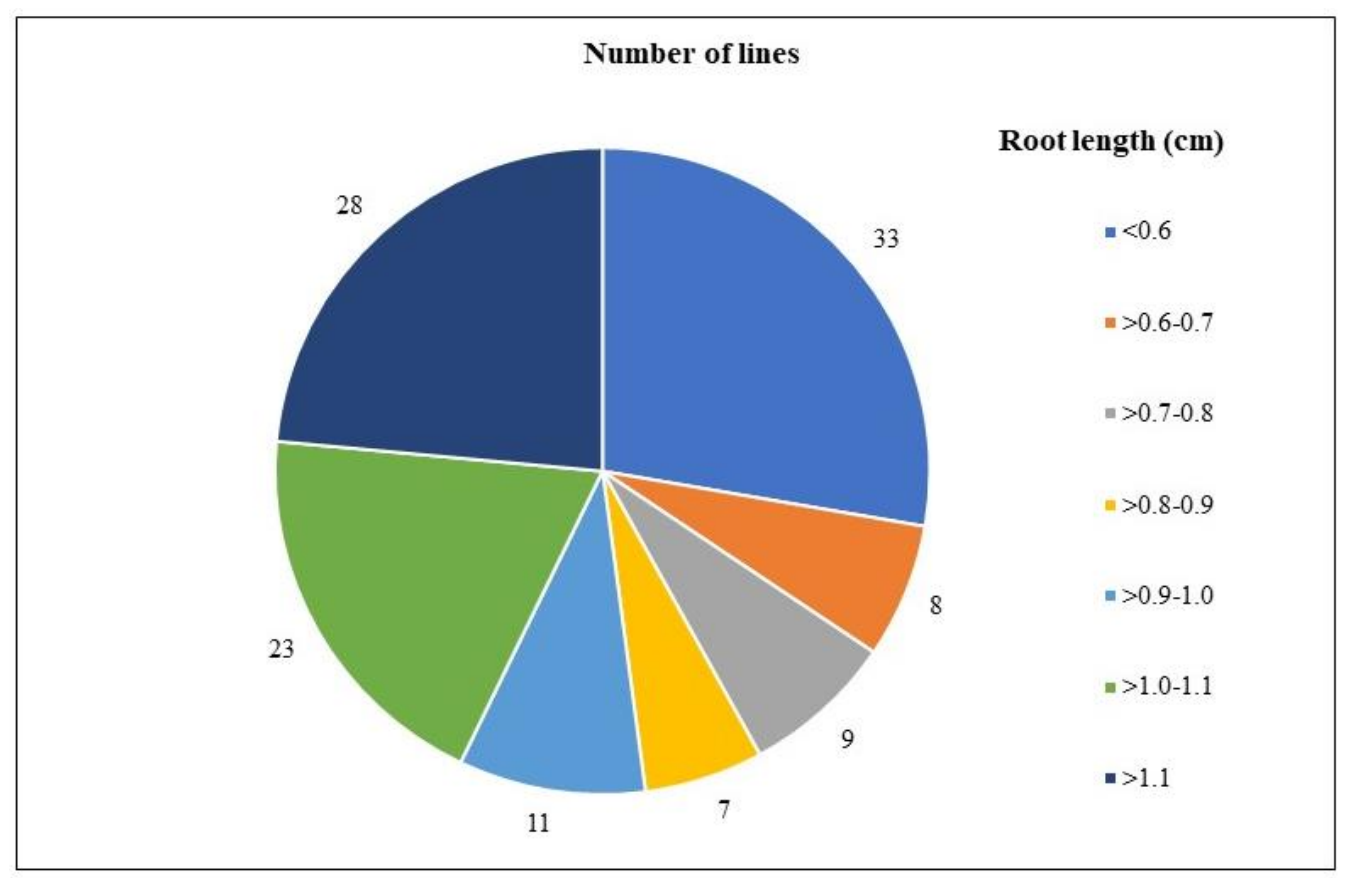

Figure 1. Root length of contrasting lines in the 'OM6830'/'AS996'//'AS996' population treated with $150 \mathrm{mg} \mathrm{L}^{-1} \mathrm{FeCl}_{2}$ for 14 days.

\section{RESULTS AND DISCUSSION}

\section{Phenotypic analysis}

Various traits, such as root growth and leaf bronzing indexes, have been reported to be associated with iron tolerance at the early growth stage of rice and thus can be used as selection criteria (Sahrawat and Audebert, 2000; Becker and Asch, 2005; Wu et al., 2014).

The 119 lines screened for their tolerance to $\mathrm{Fe}^{2+}$ at the seedling stage after 4 weeks were categorized into seven groups on the basis of root length (Figure $1)$. The group with the lowest root length contained 33 rice lines $(<0.6 \mathrm{~cm})$, which accounted for $27.7 \%$ of the analyzed population. The next most important population of 27 lines and the tolerant parental genotype were in the root length group $>1.1 \mathrm{~cm}$ and accounted for $23.5 \%$ of the total population. The 23 lines with the root length of $1.0-1.1 \mathrm{~cm}$ comprised $19.3 \%$ of the total population. Moreover, nine rice lines, including the susceptible parental genotype, were in the root length group of $0.7-0.8 \mathrm{~cm}$, comprising $7.5 \%$ of the population of 119 rice genotypes.

In acidic soils, the solubility and high plant availability of iron lead to ironinduced toxicity (Hu et al., 2014). The development of rice cultivars with increased tolerance to $\mathrm{Fe}^{2+}$ is an important strategy for improving rice production. Roots play an essential role in iron tolerance in rice. Iron is removed from the roots by parenchymal-derived oxygen or through the enzymatic oxidation of $\mathrm{Fe}^{2+}$ into $\mathrm{Fe}^{3+}$, which forms precipitates in the form of iron plaques at the root surface (Wu et al., 2014; Stein et al., 2019). Roots have the capability to store iron in their tissues and limit iron transfer from the roots to shoots (Stein et al., 2014) to avoid the excessive accumulation of iron in leaves and maintain homeostasis ( $\mathrm{Da}$ Silveira et al., 2007; Aung and Masuda, 2020).

The results indicated that out of 119 lines, 23 lines and the tolerant parental line 'AS996' possessed high tolerance with the score of 1 (Figure 2). A total of 29 lines had the score of 3,17 


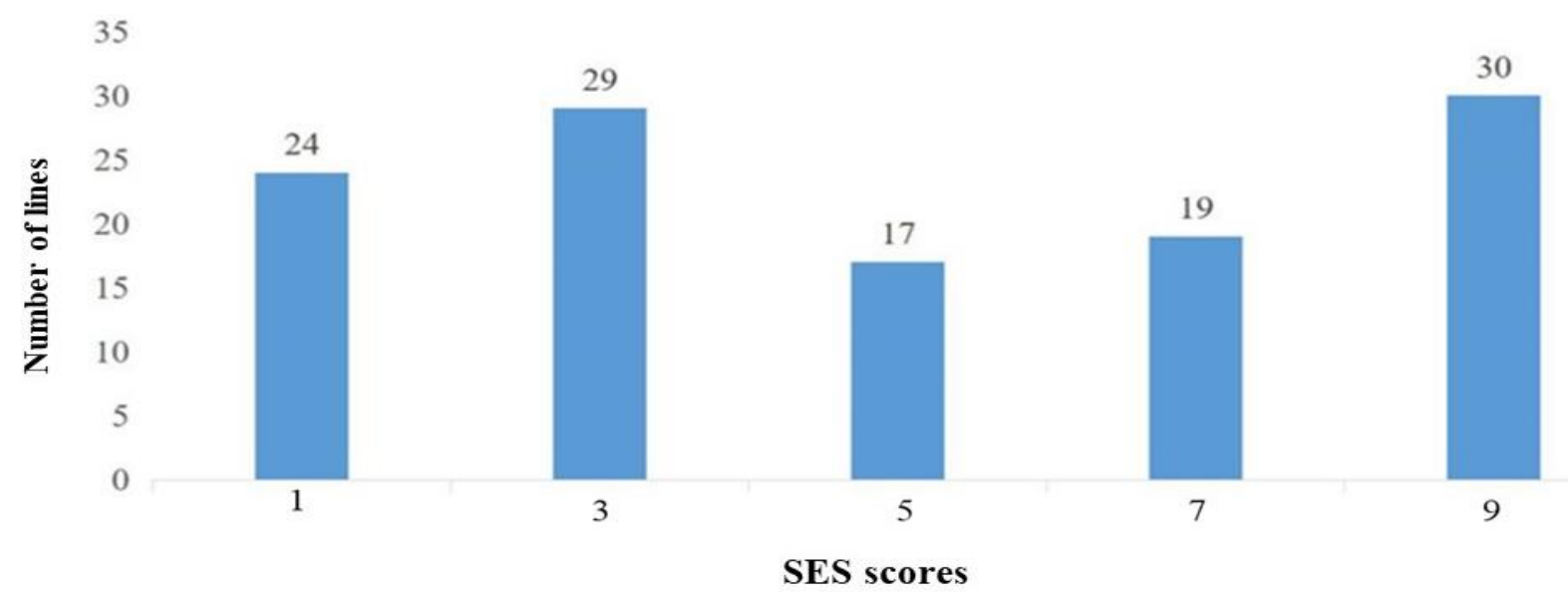

Figure 2. Leaf bronzing score of contrasting lines in the 'OM6830'/'AS996'//'AS996' population treated with $150 \mathrm{mg} \mathrm{L}^{-1} \mathrm{FeCl}_{2}$ for 14 days.

lines had the score of 5 , and another 17 lines had the score of 7 (Figure 2). The largest number of lines, i.e., 29 lines and the susceptible parental line 'OM6830', showed iron toxicity symptoms with the score of 9. Leaf bronzing is one of the most essential traits for the identification of tolerant genotypes under iron-toxicity conditions (Wu et al., 2014). The tolerant parent 'AS996' used in this study was derived from an 'IR64' $\times 0$. rufipogon cross. Mendoza et al. (2003) screened wild accessions of $O$. rufipogon at the iron concentration of $400 \mathrm{ppm}$ and identified three accessions that were highly resistant and could be a possible resource of useful genes for iron tolerance in rice. The current results verified that the iron responses of the tolerant parental line 'AS996' and the lines of the tolerant groups (SES scores of 1 and 3 ) were significantly different from those of the susceptible parent 'OM6830' and the lines in the susceptible group (scores of 5,7 , and 9).

Altogether, three phenotypic classes of rice lines were defined on the basis of iron tolerance in the current study: highly tolerant (SES score of 1 ), less tolerant (SES score of 3), and susceptible (SES score greater than 3). The threshold of toxic iron concentration for rice ranges from $10 \mathrm{mg} \mathrm{L}^{-1}$ to $300 \mathrm{mg}$
$\mathrm{L}^{-1}$ in accordance with the form of nutrient supply and the tolerance of the rice genotypes (De-Dorlodot et al., 2005; Elec et al., 2013). Solutions with $\mathrm{FeCl}_{2}$ concentrations of $150 \mathrm{mg} \mathrm{L}^{-1}$ (Fageria and Robelo, 1987), $200 \mathrm{mg} \mathrm{L}^{-1}$ (Yamaguchi and Yoshida, 1981), and $300 \mathrm{mg} \mathrm{L}^{-1}$ (Nugraha et al., 2016) have been tested for the screening of rice seedlings for iron toxicity. In this study, the iron concentration of $150 \mathrm{mg} \mathrm{L}^{-1}$ was found to be highly suitable for screening $\mathrm{Fe}^{2+}$ tolerant lines. Finally, the 23 most tolerant $\mathrm{BC}_{3} \mathrm{~F}_{2}$ rice lines $(1-23)$ with the score of 1 and the root length of $>1.1 \mathrm{~cm}$ were selected as the most promising tolerant lines and subjected to genotypic analysis.

\section{Genotypic analysis}

Two markers, i.e., RM6 and RM240 on chromosome 2 at 200-210 and 300-310 bp, respectively, were linked to iron toxicity tolerance. Marker RM6 was polymorphic. The susceptible parent 'OM6830' contained allele A with a molecular size of $210 \mathrm{bp}$, whereas the tolerant line 'AS996' contained allele B with a size of $200 \mathrm{bp}$. Seven rice lines (2, $7,12,13,14,15$, and 17) exhibited a similar banding pattern as 'AS996' for marker RM6 (Figure 3C). Six lines (3, 7, $8,11,15$, and 16) displayed similar 

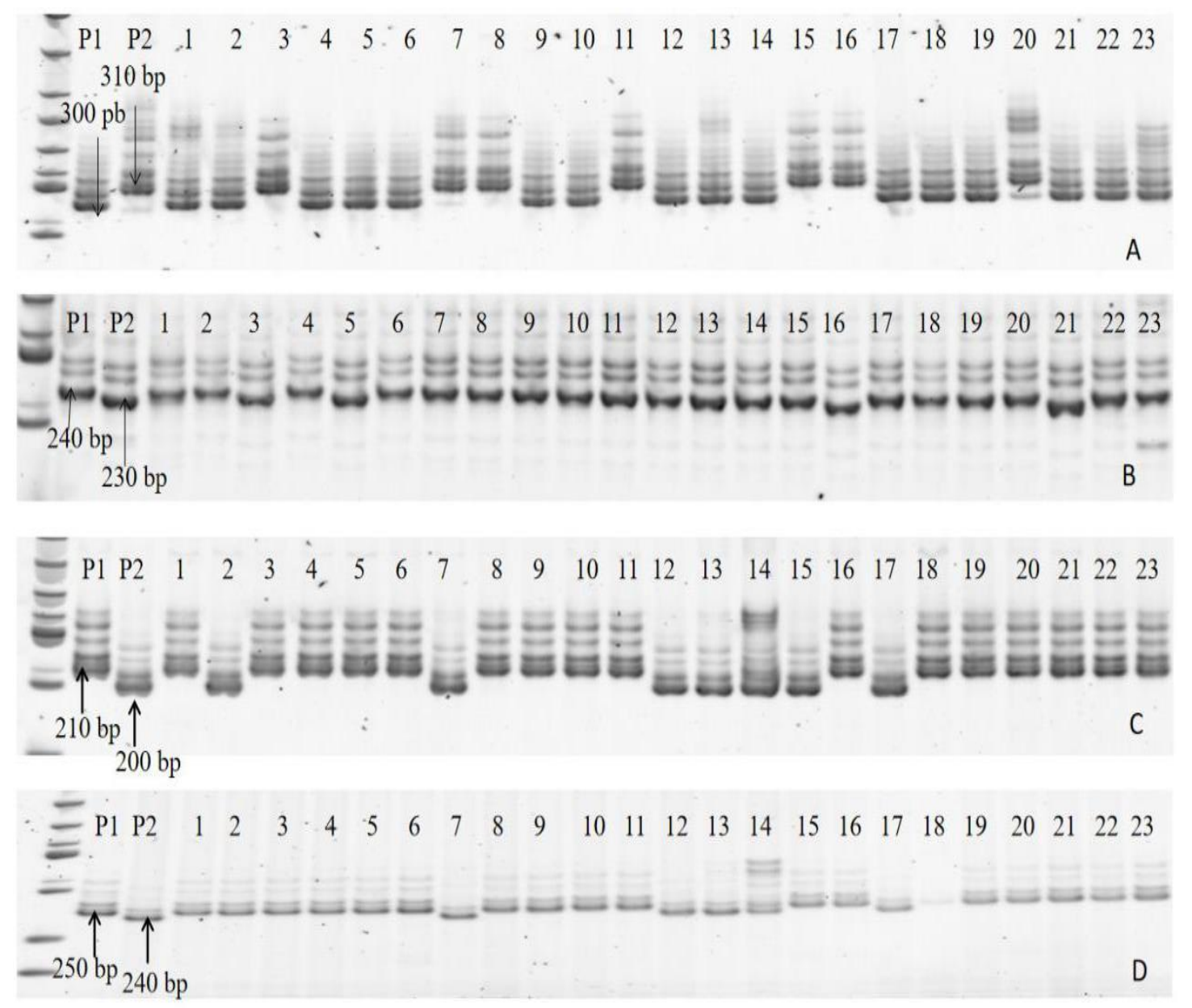

Figure 3. Banding profiles of some lines obtained with primer RM240 (A), RM252 (B), RM6 (C), and $\mathrm{RM} 451$ (D) in the $\mathrm{BC}_{3} \mathrm{~F}_{2}$ population of 'OM6830'/'AS 996//'AS996'. Lane 1: 'OM6830' (A), lane 2: 'AS996' (B), lanes from 4 to 25 are the $23 \mathrm{BC}_{3} \mathrm{~F}_{2}$ lines, which were named from $1-23$.

banding patterns for RM240, indicating that they possessed an iron toxicity tolerance gene with the molecular size of 310 bp that was carried by the parental genotype 'AS996' (Figure 3A).

Rasheed et al. (2021) reported that iron toxicity leads to the reduction in the uptake of numerous essential nutrients, such as nitrogen, phosphorous, and potassium. Wan et al. (2005) showed that the QTL for leaf bronzing index located in the RM6-RM240 region on chromosome 2 is also linked to the QTL for potassium uptake under potassium deficiency stress in the RZ58-CD0686 region. Furthermore, the locations of $O$. nivara-derived QTL, such as qFe2.1, qFe3.1, qFe8.2, and $q Z n 12.1$, were consistent in both $\mathrm{BC}_{2} \mathrm{~F}_{3}$ mapping populations derived from the crosses of $O$. sativa cV 'Swarna' and two different accessions of Oryza nivara (Swamy et al., 2018). QTLs for iron concentration were located in the RM106 and RM6 regions on chromosome 2 in population 1 (Swamy et al., 2018).

In addition to those two markers, two other markers (RM252 and RM451) at 230-240 and 240-250 bp on chromosome 4 were linked to iron tolerance. The parents were polymorphic for the marker RM252. The susceptible parental line 'OM6830' carried allele A with the 
molecular size of $240 \mathrm{bp}$, whereas the tolerant parental line 'AS996' carried allele $B$ with the molecular size of $230 \mathrm{bp}$. The iron tolerance gene of the four rice lines $(3,5,16$, and 21$)$ was similar to that of tolerant parental line 'AS996' with the molecular size of 230 bp of RM252 (Figure $3 B)$. Five lines $(7,12,13,14$, and 17) carried an iron tolerance gene that was similar to the iron tolerance gene of the tolerant-parent 'AS996' with the molecular size of 240 bp carried by RM451 (Figure 3D).

QTL for iron toxicity have been identified by using DNA markers (Wan et al., 2003; Zhang et al., 2017). The combination of QTL determination with molecular marker-assisted selection has become effective in many breeding programs through precise genotyping (Boopathi, 2020). Wan et al. (2005) studied the $F_{2}$ and equivalent $F_{3}$ populations derived from 'Longza 8503' $\times$ 'IR64' and found that QTL controlling leaf bronzing index are located in the RM6RM240 region on chromosome 2 and the RM252-RM451 region on chromosome 4. Two markers, namely, RM252 and RM451, on chromosome 4 are identical to the QTL for decreased chlorophyll content on a rice function map (Wan et al., 2005).

In the current study, line $\mathrm{BC}_{3} \mathrm{~F}_{2}-7$ was identified as the most tolerant genotype with the markers RM240, RM6, and RM451. This line was completely tolerant of $\mathrm{Fe}^{2+}$ at the concentration of $150 \mathrm{mg} \mathrm{L}^{-1}$. Thus, the PCR screening of this line was carried out through two consecutive self-pollinated generations (from $\mathrm{BC}_{3} \mathrm{~F}_{1}$ to $\mathrm{BC}_{3} \mathrm{~F}_{2}$ ). The $\mathrm{PCR}$ test results $\left(B C_{3} F_{2}\right.$ generation) confirmed that tolerance genes had been transferred into the desired rice lines. The genotypic results showed that the 23 tolerant lines and the tolerant parental line 'AS996' can be directly subjected to MAS to identify iron toxicity tolerance. The identification of robust markers for traits is essential for the incorporation of tolerance through MAS breeding. In previous reports, the loci associated with iron toxicity tolerance on chromosome 1 were localized in the same region wherein several QTL had been previously detected in different studies (Wu et al., 2014; Dufey et al., 2015). In the current study, markers RM6 and RM240 on chromosome 2 were quite closely associated with tolerance to iron toxicity in the existing rice population (Figure 3A, C). These results were also consistent with the past findings of QTL analysis for aluminum tolerance in rice via marker-assisted selection (Buu et al., 2010). Therefore, identifying the rice lines containing tolerance genes for further evaluation and selection is possible.

\section{Yield and yield components of the selected rice lines}

The 23 developed $\mathrm{BC}_{3} \mathrm{~F}_{3}$ lines were further screened for their genetic potential for yield and yield components (Table 4 ). The results showed that plant heights ranged from $102 \mathrm{~cm}$ to $120 \mathrm{~cm}$. Among the 23 lines, $\mathrm{BC}_{3} \mathrm{~F}_{3}-7$ and $\mathrm{BC}_{3} \mathrm{~F}_{3}-15$ had a higher number of tillers (11 and 10) than their parental genotypes (seven and nine tillers) $(P<0.05)$. Three lines, namely, $\mathrm{BC}_{3} \mathrm{~F}_{3}-7, \mathrm{BC}_{3} \mathrm{~F}_{3}-15$, and $\mathrm{BC}_{3} \mathrm{~F}_{3}-19$, showed the highest number of filled grains of 122 , 107 , and 100, respectively, whereas the parental checks had 61 and 85 filled grains. Grain yield ranged from $6 \mathrm{~g}$ to 35 $\mathrm{g}$ per plant. The line $\mathrm{BC}_{3} \mathrm{~F}_{3}-7$ presented $\mathrm{a}$ higher yield $(35.4 \mathrm{~g})$ than the parental checks ( 8.9 and $17 \mathrm{~g}$ ). The grain yield per plant of $\mathrm{BC}_{3} \mathrm{~F}_{3}-7$ (35.4 g) was 4 -fold and 2 -fold higher than those of the susceptible $(8.9 \mathrm{~g})$ and tolerant $(17 \mathrm{~g})$ parental lines, respectively. In the current study, at $\mathrm{pH}<$ 4.0, the rice lines $\mathrm{BC}_{3} \mathrm{~F}_{3}-7$ and $\mathrm{BC}_{3} \mathrm{~F}_{3}-15$ showed significantly higher number of tillers, 1000-grain weight, filled grain, and grain yield and fewer unfilled grains than other lines. These indexes can be used as selection criteria in future breeding programs.

The selection of iron-tolerant rice lines is a continuous process involving hybridization, strain selection, and adaptation testing in acid-affected areas. Approximately $50 \%$ of the area in the Mekong Delta region of Vietnam consists of acid sulfate soil and accounts for nearly $70 \%$ of the area's agricultural land (Bong 
Table 4. Yield and yield components of the selected $\mathrm{Fe}^{2+}$-tolerant rice lines in the $\mathrm{BC}_{3} \mathrm{~F}_{3}$ population.

\begin{tabular}{|c|c|c|c|c|c|c|c|}
\hline Rice genotype & $\mathrm{PH}$ & NT & $\mathrm{PL}$ & $\mathrm{FG}$ & UFG & $W-1000$ & GY \\
\hline $\mathrm{P}_{1}\left({ }^{\prime} \mathrm{OM} 6830^{\prime}\right)$ & $107^{\mathrm{fg}}$ & $7^{\mathrm{de}}$ & $23.7^{\text {cdef }}$ & $61^{n}$ & $49.2^{g}$ & $20.9^{\text {hijk }}$ & $8.9^{\mathrm{kl}}$ \\
\hline$P_{2}$ ('AS996') & $105^{\mathrm{hi}}$ & $9^{b c}$ & $24.3^{\text {abcde }}$ & $86^{f}$ & $26.3^{n}$ & $21.9^{\text {fghijk }}$ & $17.0^{\text {cd }}$ \\
\hline $\mathrm{BC}_{3} \mathrm{~F}_{3}-1$ & $106^{\mathrm{fgh}}$ & $6^{\text {ef }}$ & $22.2^{\mathrm{dgh}}$ & $81^{i}$ & $37.1^{\mathrm{kl}}$ & $22.5^{\text {defghi }}$ & $11.0^{\mathrm{ij}}$ \\
\hline $\mathrm{BC}_{3} \mathrm{~F}_{3}-2$ & $110^{\text {de }}$ & $5^{f}$ & $21.0^{g h i}$ & $54^{9}$ & $33.3^{\mathrm{m}}$ & $23.2^{\mathrm{efg}}$ & $6.2^{\mathrm{m}}$ \\
\hline $\mathrm{BC}_{3} \mathrm{~F}_{3}-3$ & $106^{\mathrm{fh}}$ & $6^{\text {ef }}$ & $20.7^{\text {hi }}$ & $87^{f}$ & $65.1^{\mathrm{b}}$ & $24.2^{\text {bcde }}$ & $12.6^{\mathrm{fghi}}$ \\
\hline $\mathrm{BC}_{3} \mathrm{~F}_{3}-4$ & $113^{b c}$ & $7^{\text {de }}$ & $20.0^{i}$ & $86^{f}$ & $64.5^{\mathrm{b}}$ & $23.4^{\text {defg }}$ & $14.1^{\mathrm{efg}}$ \\
\hline $\mathrm{BC}_{2} \mathrm{~F}_{3}-5$ & $112^{\mathrm{cd}}$ & $8^{\mathrm{cd}}$ & $24.3^{\text {abcde }}$ & $78^{j}$ & $23.0^{\circ}$ & $23.1^{\text {defg }}$ & $14.4^{\mathrm{ef}}$ \\
\hline $\mathrm{BC}_{3} \mathrm{~F}_{3}-6$ & $118^{a}$ & $9^{b c}$ & $20.5^{\mathrm{hi}}$ & $67^{\prime}$ & $73.0^{\mathrm{a}}$ & $20.6^{\mathrm{ijk}}$ & $12.4^{\mathrm{hi}}$ \\
\hline $\mathrm{BC}_{3} \mathrm{~F}_{3}-7$ & $108^{\text {ef }}$ & $11^{a}$ & $24.2^{\mathrm{abcde}}$ & $122^{a}$ & $22.3^{\circ}$ & $26.4^{a}$ & $35.4^{a}$ \\
\hline $\mathrm{BC}_{3} \mathrm{~F}_{3}-8$ & $113^{\mathrm{bc}}$ & $8^{\mathrm{cd}}$ & $25.7^{\mathrm{ab}}$ & $67^{1}$ & $53.5^{\mathrm{e}}$ & $23.8^{\text {bcdef }}$ & $12.8^{\mathrm{fghi}}$ \\
\hline $\mathrm{BC}_{2} \mathrm{~F}_{3}-9$ & $111^{\mathrm{cd}}$ & $7^{\text {de }}$ & $23.0^{\text {def }}$ & $59^{o p}$ & $61.0^{c}$ & $22.2^{\text {efghij }}$ & $9.2^{\mathrm{kl}}$ \\
\hline $\mathrm{BC}_{3} \mathrm{~F}_{3}-10$ & $118^{a}$ & $6^{\mathrm{ef}}$ & $25.3^{a b c}$ & $84^{g}$ & $50.4^{\mathrm{fg}}$ & $20.5^{\mathrm{jk}}$ & $10.3^{j \mathrm{k}}$ \\
\hline $\mathrm{BC}_{3} \mathrm{~F}_{3}-11$ & $102^{j}$ & $8^{\mathrm{cd}}$ & $24.0^{\text {bcdef }}$ & $65^{\mathrm{m}}$ & $51.6^{f}$ & $22.6^{\text {defgh }}$ & $11.7^{\text {hij }}$ \\
\hline $\mathrm{BC}_{3} \mathrm{~F}_{3}-12$ & $105^{\mathrm{hi}}$ & $5^{f}$ & $22.7^{\mathrm{efg}}$ & $68^{1}$ & $45.9^{h}$ & $24.2^{b c} d$ & $8.2^{1}$ \\
\hline $\mathrm{BC}_{3} \mathrm{~F}_{3}-13$ & $112^{\mathrm{cd}}$ & $7^{\mathrm{de}}$ & $24.7^{\mathrm{abcd}}$ & $82^{\mathrm{hi}}$ & $43.3^{i j}$ & $22.0^{\text {fghijk }}$ & $12.6^{\mathrm{fghi}}$ \\
\hline $\mathrm{BC}_{3} \mathrm{~F}_{3}-14$ & $108^{\text {ef }}$ & $7^{\text {de }}$ & $24.3^{\text {abcde }}$ & $83^{\text {gh }}$ & $38.2^{\mathrm{kl}}$ & $21.8^{g h i j k}$ & $12.7^{\mathrm{fghi}}$ \\
\hline $\mathrm{BC}_{3} \mathrm{~F}_{3}-15$ & $107^{\mathrm{fg}}$ & $10^{\mathrm{ab}}$ & $21.0^{\text {ghi }}$ & $107^{b}$ & $38.7^{k}$ & $25.6^{\mathrm{ab}}$ & $27.4^{b}$ \\
\hline $\mathrm{BC}_{3} \mathrm{~F}_{3}-16$ & $110^{\mathrm{de}}$ & $9^{b c}$ & $22.7^{\mathrm{efg}}$ & $92^{\mathrm{e}}$ & $42.1^{\mathrm{j}}$ & $21.7^{\text {ghijk }}$ & $18.0^{c}$ \\
\hline $\mathrm{BC}_{3} \mathrm{~F}_{3}-17$ & $113^{\mathrm{bc}}$ & $6^{\text {ef }}$ & $23.7^{\text {cdef }}$ & $98^{d}$ & $43.9^{i}$ & $20.1^{k}$ & $11.8^{\text {hij }}$ \\
\hline $\mathrm{BC}_{3} \mathrm{~F}_{3}-18$ & $100^{i j}$ & $8^{\mathrm{cd}}$ & $19.2^{i}$ & $58^{p}$ & $53.9^{e}$ & $25.4^{a b c}$ & $11.8^{\text {hij }}$ \\
\hline $\mathrm{BC}_{3} \mathrm{~F}_{3}-19$ & $103^{i j}$ & $7^{\text {de }}$ & $26.0^{a}$ & $100^{c}$ & $22.1^{\circ}$ & $22.0^{\text {fghijk }}$ & $15.4^{\text {de }}$ \\
\hline $\mathrm{BC}_{3} \mathrm{~F}_{3}-20$ & $115^{b}$ & $6^{\text {ef }}$ & $23.8^{\text {bcdef }}$ & $84^{g}$ & $33.7^{\mathrm{m}}$ & $23.6^{\text {cdefg }}$ & $11.9^{\text {hij }}$ \\
\hline $\mathrm{BC}_{3} \mathrm{~F}_{3}-21$ & $108^{\mathrm{ef}}$ & $9^{b c}$ & $26.0^{a}$ & $64^{\mathrm{m}}$ & $56.6^{d}$ & $22.4^{\text {defghi }}$ & $12.9^{\mathrm{fgh}}$ \\
\hline $\mathrm{BC}_{3} \mathrm{~F}_{3}-22$ & $115^{b}$ & $8^{\mathrm{cd}}$ & $23.0^{\text {def }}$ & $76^{k}$ & $32.1^{\mathrm{m}}$ & $22.1^{\text {efghij }}$ & $13.4^{\mathrm{fgh}}$ \\
\hline $\mathrm{BC}_{3} \mathrm{~F}_{3}-23$ & $120^{a}$ & $9^{b c}$ & $23.0^{\text {def }}$ & $60^{\text {no }}$ & $36.6^{1}$ & $22.8^{\text {defgh }}$ & $12.3^{\mathrm{ghi}}$ \\
\hline CV\% & 1.28 & 13.30 & 4.32 & 1.27 & 2.28 & 4.40 & 7.26 \\
\hline
\end{tabular}

Means followed by different trailing letters in the same column show a statistically significant difference $(p<0.05)$. Note: Plant height $(\mathrm{PH}, \mathrm{cm})$; Number of tillers (NT); Panicle length $(\mathrm{PLL}, \mathrm{cm})$; Filled grain (FG); unfilled grain (UFG, $\%) ; 1000$-weight $(\mathrm{W}-1000, \mathrm{~g})$; grain yield $(\mathrm{GY}, \mathrm{g})$. $\mathrm{P}_{1}$, susceptible parent; $\mathrm{P}_{2}$, tolerant parent.

et al., 2018). Acidic soil damages plants through many factors, including iron and aluminum toxicity. At a very low soil $\mathrm{pH}$ $(<4.0)$, the strong reduction activity of $\mathrm{Fe}^{3+}$ into $\mathrm{Fe}^{2+}$ may increase available iron in the root zone, as well as iron absorption and uptake, thereby resulting in iron toxicity (Rout and Sahoo, 2015). The physiochemical activity of rice plants may decrease drastically, thus weakening root functions (Sahrawat, 2005). Krohling et al. (2016) suggested that iron is 1000 times more soluble at $\mathrm{pH} 3.0$ than at $\mathrm{pH}$ 6.0 .

Efforts in the development of irontolerant cultivars for the acidic soils of the Mekong Delta have made initial achievements. The use of molecular markers to aid the selection of tolerant genotypes results in better performance than direct field screening experiments. Various rice genotypes have varying levels of tolerance for certain toxins and growing conditions. In addition, a significant difference exists between laboratory testing and actual adaptation when it comes to the survival and development of a variety because of their dependence on farmers' needs. With the release of numerous tolerant varieties, the breeding program for iron toxicity continues to fulfill farmers' needs while enhancing the characteristics of existing varieties (Sikirou et al., 2015). Therefore, tolerant 
genotypes were selected and evaluated for yield and yield components to eliminate unwanted genotypes before being assessed in paddy field trials in various ecological regions. The present research showed that the rice lines $\mathrm{BC}_{3} \mathrm{~F}_{3}$ 7 and $\mathrm{BC}_{3} \mathrm{~F}_{3}-15$ exhibited enhanced growth and the best performance for yield-related traits in an ironcontaminated area.

\section{CONCLUSIONS}

The $\mathrm{BC}_{3} \mathrm{~F}_{2}$ rice population was phenotyped for iron toxicity tolerance by using root lengths and leaf bronzing scores after 4 weeks of growth, including 14 days in nutrient solution, followed by 14 days of exposure to $150 \mathrm{mg} \mathrm{L}^{-1} \mathrm{Fe}^{2+}$, a level that is normally toxic to rice. Different rice lines in the $\mathrm{BC}_{3} \mathrm{~F}_{2}$ population that were tolerant to iron toxicity were identified by using the two molecular markers RM6 and RM240 on chromosome 2. $\mathrm{BC}_{3} \mathrm{~F}_{3}-7$ and $\mathrm{BC}_{3} \mathrm{~F}_{3}-15$ were the most tolerant genotypes. They presented increased tillers, 1000-grain weight, filled grain, and grain yield with few unfilled grains under iron contamination conditions in the field. These rice lines could be further studied and used in future breeding programs to increase rice production in the ironcontaminated areas of the Mekong Delta, Vietnam.

\section{ACKNOWLEDGMENTS}

Authors are greatly indebted to Cuu Long Delta Rice Research Institute for providing rice breeding materials for this study. The authors acknowledge Prof. Dr. Nguyen Thi Lang for their technical help.

\section{REFERENCES}

Aung MS, Masuda H (2020). How does rice defend against excess iron? Physiological and molecular mechanisms. Front. Plant Sci. 11: 1102.
Becker M and Asch F (2005). Iron toxicity in rice-conditions and management concepts. J. Soil. Sci. Plant Nutr. 168: 558-573.

Bong BB, Bo NV, Son NH, Tung LT, Tu TQ, Toan TQ, Yen BT, Trung ND, Labios RV, Sebastian LS (2018). Adaptation options for rice-based cropping systems in climate risk-prone provinces in the Mekong River Delta: An assessment report. Agric. Food Secure. 245: 1-64.

Boopathi NM (2020). Marker-Assisted Selection (MAS). In: Genetic mapping and marker-assisted selection. Springer India. pp. 343-388.

Bresolin APS, Santos RS, Wolter RCD, de Sousa RO, da Maia LC, Costa de Oliveira A (2019). Iron tolerance in rice: an efficient method for performing quick early genotype screening. BMC Res. Notes 12: 361.

Buu BC, Ha PTT, Cuong NV, Lang NT, Thuan ND (2010). QTL (Quantitative trait local) analysis of tolerance aluminum in rice (Oryza sativa L.) via markerassisted selection. Sci. Tech. J. Agric. Rural Develop. 1: 3-9.

Buu BC, Lang NT (1997). Germplasm evaluation assisted by DNA markers In: CLRRI (Ed.), CLRRI Research Note from 1977 to 1997. Ho Chi Minh City, Vietnam: Nong Nghiep Publisher. pp. 83-86.

Buu BC, Lang NT (2007). Rice conventional and molecular breeding at CLRRI (1977-2007). Omonrice 15: 1-11.

Chakravarthi BK, Naravaneni R (2006). SSR marker-based DNA fingerprinting and diversity study in rice (Oryza sativa. L). Afr. J. Biotechnol. 5(9): 684-688.

Collard BCY, Mackill DJ (2007). Markerassisted selection: an approach for precision plant breeding in the twentyfirst century. Royal Soci. 363: 557572.

Da-Silveira VC, de Oliveira AP, Sperotto RA, Espindola LS, Amaral L, Dias JF, et al. (2007). Influence of iron on mineral status of two rice (Oryza sativa L.) cultivars. Braz. J. Plant Physiol. 19: 127-139.

Dabi T, Khanna VK (2018). Effect of climate change on rice. Agrotech. 7: 1-7.

De-Dorlodot S, Lutts S, Bertin P (2005). Effects of ferrous iron toxicity on the growth and mineral composition of an interspecific rice. J. Plant Nutr. 28(1): 1-20. 
Dufey I, Draye X, Lutts S, Lutts S, Bertin P (2015). Novel QTLs in an interspecific backcross Oryza sativa $\times$ Oryza glaberrima for resistance to iron toxicity in rice. Euphytica 204: 609625.

Elec V, Quimio CA, Mendoza R, Sajise AGC, Beebout SEJ, Gregorio GB, Singh RK (2013). Maintaining elevated $\mathrm{Fe}^{2+}$ concentration in solution culture for the development of a rapid and repeatable screening technique for iron toxicity tolerance in rice (Oryza sativa L.). Plant and Soil 372(1-2): 253-264.

Fageria NK, Robelo NA (1987). Tolerance of rice cultivar to iron toxicity. J. Plant Nutr. 10(6): 653-661.

FAO (2021). World rice trade would grow $5.6 \%$ in 2021: FAO.

$\mathrm{Hu} H W$, Xu ZH, He JZ (2014). Ammoniaoxidizing archaea play a predominant role in acid soil nitrification. Adv. Agro. 125: 261-302.

IRRI (2002). Standard evaluation system for rice. International Rice Research Institute, Manila, Philippines.

Krohling CA, Eutrópio FJ, Bertolazi AA, Dobbss LB, Campostrini E, Dias T, Ramos AC (2016). Ecophysiology of iron homeostasis in plants. Soil Sci. Plant Nutr. 62: 39-47.

Lang NT (2002). Protocol for basics of biotechnology. Agricultural Publish House. Ho Chi Minh, Vietnam.

Lincoln M, Sunil KV, Saugato S, Jawaharlal K (2018). Potential applications of molecular markers in plant. Curr. Trends Biomed. Eng. Biosci. 12(4): 555844.

Liu H, Soomro A, Zhu Y, Qiu X, Chen K, Zheng T, Yang L, Xinga D, Xu J (2016). QTL underlying iron and zinc toxicity tolerances at seedling stage revealed by two sets of reciprocal introgression populations of rice (Oryza sativa L.). Crop J. 4: 280-290.

Mahender A, Swamy BPM, Anandan A (2019). Tolerance of iron-deficient and -toxic soil conditions in rice. Plants 8: 31.

Mendoza RD, Moliñawe JA, Gregorio GB, Guerta CQ, Brar DS (2008). Genetic variability of tolerance for iron toxicity in different species of Oryza and their derivatives. Adv. Rice Genet. 154-157.

Nagaraju J, Kathirvel M, Kumar RR, Siddiq EA, Hasnain SE (2002). Genetic analysis of traditional and evolved basmati and non-basmati rice varieties by using fluorescence-based ISSR-PCR and SSR markers. Proc. Natl. Acad. Sci. 99: 5836-5841.

Nugraha Y, Ardie SW, Ghulammahdi M, Suwarno, Aswidinnoor H (2016). Nutrient culture media with agar is effective for early and rapid screening of iron toxicity tolerance in rice. J. Crop Sci. Biotechnol. 19(1): 61-70.

Nugroho N, Kurniasih B, Utami SNH, Yusuf WA, Rumanti IA, Agustiani N, Margaret S (2021). Effect of soil leaching and organic matter on $\mathrm{Fe}^{2+}$ concentration and rice yields in acid sulfate soils. Conf. Ser.: Earth Environ. Sci. 824: 012085.

Panaud O, Chen X, McCouch SR (1996). Development of microsatellite markers and characterization of simple sequence length polymorphism (SSLP) in rice (Oryza sativa L.). Genome 252: 597-607.

Platten JD, Cobb JN, Zantua RE (2019). Criteria for evaluating molecular markers: comprehensive quality metrics to improve marker-assisted selection. PIOS ONE. 14(1): e0210529.

Rasheed A, Wassan GM, Khanzada $H$, Solangi AM, Aamer M, Han R, Bian J, Wu Z (2021). QTL underlying iron toxicity tolerance at seedling stage in backcross recombinant inbred lines (BRILs) population of rice using high density genetic map. Not. Bot. Horti. Agrobot. Cluj. Napoca 49(1): 12158.

Rout GR, Sahoo S (2015). Role of iron in plant growth and metabolism. Rev. Agric. Sci. 3: 1-24.

Sahrawat KL (2004). Terminal electron acceptors for controlling methane emissions from submerged rice soils. Comm. Soil Sci. Plant Anal. 35: 14011413.

Sahrawat KL (2005). Iron toxicity in wetland rice and the role of other nutrients. J. Pant Nutr. 27(8): 1471-1504.

Sahrawat KL, Audebert A (2000). Mechanisms for iron toxicity tolerance in lowland rice. J. Plant Nutr. 23: 1877-1885.

Sakiyama NS, Ramos HCCC, Caixeta ET, Pereira MG (2014). Plant breeding with marker-assisted selection in Brazil. Crop Breed. Appl. Biotechnol. 14(1): 54-60.

Santos MSD, Sanglard LMPV, Martins SCV, Barbosa ML, de Melo DC, Gonzaga WF, DaMatta FM (2019). Silicon alleviates the impairments of iron toxicity on the rice photosynthetic performance via alterations in leaf diffusive conductance 
with minimal impacts on carbon metabolism. Plant Physiol. Biochem. 143: 275-285.

Seraj F, Rahman T (2018). Heavy metals, metalloids, their toxic effect and living systems. Am. J. Plant Sci. 9: 26262643.

Sikirou M, Saito K, Achigan-Dako EG, Dramé KN, Adam A, Venuprasad R (2015). Genetic improvement of iron toxicity tolerance in rice-progress, challenges and prospects in West Africa. Plant Prod. Sci. 18(4): 423-434.

Sikirou M, Shittu A, Konaté KA, Maji AT, Ngaujah AS, Sanni KA, Ogunbayo SA, Akintayo I, Saito K, Dramé KN, Ahanchédé $A$ and Venuprasadc $R$ (2018). Screening African rice (Oryza glaberrima) for tolerance to abiotic stresses: I. Iron toxicity. Field Crops Res. 220: 3-9.

Stein RJ, Duarte GL, Scheunemann L, Spohr MG, de Araújo Júnior AT, Ricachenevsky FK, Rosa LMG, Zanchin NIT, Santos RPd, Fett JP (2019). Genotype Variation in Rice (Oryza sativa L.) Tolerance to iron toxicity might be linked to root cell wall lignification. Front. Plant Sci. 10: 746, doi: $10.3389 /$ fpls.2019.00746.

Stein RJ, Lopes RJ, Fett SIG (2014). Iron toxicity in field-cultivated rice: contrasting tolerance mechanisms in distinct cultivars. Theo. Exp. Plant Physiol. 26: 135-146.
Swamy BPM, Kaladhar K, Anuradha K, Batchu AK, Longvah T, Sarla N (2018). QTL analysis for grain iron and zinc concentrations in two $O$. nivara derived backcross populations. Rice Sci. 25(4): 197-207.

Wan J, Zhai H, Wan J, Ikehashi H (2003). Detection and analysis of QTLs for ferrous iron toxicity tolerance in rice, Oryza sativa L. Euphytica 131: 201206.

Wan JL, Zhai HQ, Wan JM (2005). Mapping of QTLs for ferrous iron toxicity tolerance in rice (Oryza sativa L.). Yi Chuan Xue Bao 32: 1156-1166.

Wu LB, Shhadi MY, Gregorio G, Matthus E, Becker M, Frei M (2014). Genetic and physiological analysis of tolerance to acute iron toxicity in rice. Rice 7: 8, doi: 10.1186/s12284-014-0008-3.

Yamaguchi M, Yoshida S (1981). Physiological mechanism of rice tolerance for iron toxicity. The International Rice Research Institute, Manila, Philippines.

Zhang J, Chen K, Pang Y, Naveed SA, Zhao X, Wang $X$, Xang $Y$, Dingkuhn $M$, Pasuquin J, Li Z, Xu J (2017). QTL mapping and candidate gene analysis of ferrous iron and zinc toxicity tolerance at seedling stage in rice by genome-wide association study. BMC Genomics 18: 828, DOI $10.1186 / \mathrm{s} 12864-017-4221-$ 5. 